\title{
Herpes Simplex Virus Infection in the Newborn
}

\author{
O. PETTAY, P. LEINIKKI, M. DONNER, and K. LAPINLEIMU \\ From the Children's Hospital and Department of Virology, University of Helsinki, and the State Serum Institute, \\ Helsinki, Finland
}

\begin{abstract}
Pettay, O., Leinikki, P., Donner, M., and Lapinleimu, K. (1972). Archives of Disease in Childhood, 47, 97. Herpes simplex virus infection in the newborn. Fourteen cases of neonatal herpes simplex virus infection in 10 boys and 4 girls are described. The disease was disseminated in 9 cases. In 5 cases skin symptoms predominated, and 1 had only central nervous system symptoms. Two had a vesicular eruption when born. Six of the children with disseminated disease died.

EEG recordings were made on 7 patients: 5 had clinical symptoms compatible with encephalitis, and in these the EEG showed periodic complexes, consisting of triangular or sharp waves, a pattern described in adult cases of herpetic encephalitis.

The diagnosis was made by virus isolation and antibody titration. Herpes virus type 2 was the causative agent in all 8 cases where the type was determined. In 5 patients herpes virus antigen was demonstrated using immunofluorescence either in vesicles or throat swabs, in the early phase of the disease.

Two children with generalized disease were treated with intravenous iododeoxyuridine (IDU). The first died, but the other, treated early in his disease, recovered completely.

The clinical picture, complemented by the immunofluorescent technique for virus detection and repeated EEG recordings, should lead to the early diagnosis of herpetic encephalitis in the newborn, and warrant the use of systemic IDU treatment.
\end{abstract}

New virological and clinical data about herpes simplex virus (HSV) infection have accumulated in the past few years. The existence of two antigenically different types of HSV has been well documented (Nahmias and Dowdle, 1968; Plummer et al., 1970; Schneweis, 1962). Apart from the antigenic and biological differences, these two types also cause different clinical syndromes. Type 2 is responsible for most cases of genital HSV infections (Nahmias, Alford, and Korones, 1970; Schneweis, 1967), so that the finding that most neonatal HSV infections are also caused by type 2 (Schneweis, 1967; Nahmias et al., 1969b) gives new insight into the epidemiology of this disease. The assumption that the newborn with herpetic disease has usually been infected from a maternal genital source is strengthened by studies showing that HSV is found in cervical secretions more often in late pregnancy than earlier (Nahmias et al., 1967).

It has also been found that the clinical spectrum of newborn HSV disease is broader than previously thought. Earlier papers mostly described cases

Received 17 June 1971. with a disseminated, often fatal, form of the disease. However, as reviewed by Nahmias et al. (1970), a variety of clinical syndromes exists, some of them very mild.

Attempts at active treatment of this disease are relatively new. 5-iodo-2-deoxyuridine (IDU) and the interferon inducer polyinosinic cytidylic acid have been tried (Partridge and Millis, 1968; Golden, Bell, and McKee, 1969; Tuffli and Nahmias, 1969; Charnock and Cramblett, 1970; Bellanti, Catalano, and Chambers, 1971), the latter, to our knowledge, in one case only. Trials with IDU have met with sufficient success to justify their continuation.

This report describes clinical and virological observations concerning 14 cases of neontal HSV infection. Two cases treated systemically with IDU are described in detail.

\section{Material and Methods}

Fourteen children with a diagnosis of neonatal HSV infection were studied in the years 1964-70: 10 were admitted to the Children's Hospital, University of Helsinki, and the other 4 to the paediatric wards of 3 
different central hospitals in Finland. The hospital records were available for us for these 4 cases.

Virus isolations were made in primary human amnion cells in continuous monkey kidney cell line BSC-1, and in primary human embryonic skin cultures. Positive isolates were identified either by neutralization, or by the immunofluorescent technique with reference rabbit immune sera against both types of $\mathrm{HSV}$, as described by Nahmias et al. (1969a). Immunofluorescence was also used to study exfoliated cells from vesicles and/or throats of some patients (FA-technique, Salo et al., 1969).
Antibody titrations. A microtechnique for complement fixation (CF) was used. Antigen was a type 1 antigen grown in BSC-1 cells. Type-specific herpes virus antibodies were assayed by the immunofluorescent antibody technique (IFAT) which has been shown to differentiate the two types of antibodies in both genital and nongenital infections (Leinikki, 1971).

\section{Results}

Clinical findings. The data about the mothers and their pregnancies are summarized in Table I and the main clinical data of the patients in Table II.

TABLE I

Pregnancy Data

\begin{tabular}{|c|c|c|c|c|c|c|}
\hline \multirow{2}{*}{$\begin{array}{l}\text { Case } \\
\text { No. }\end{array}$} & \multirow{2}{*}{ Sex } & \multirow{2}{*}{$\begin{array}{c}\text { Age } \\
\text { of } \\
\text { Mother } \\
(y r)\end{array}$} & \multirow{2}{*}{ Parity } & \multicolumn{2}{|r|}{ Pregnancy } & \multirow{2}{*}{$\begin{array}{c}\text { Infant's } \\
\text { Birthweight } \\
\text { (g) }\end{array}$} \\
\hline & & & & $\begin{array}{c}\text { Duration } \\
\text { (wk) }\end{array}$ & Complications & \\
\hline $\begin{array}{r}2 \\
3 \\
4 \\
5 \\
6 \\
7 \\
8 \\
9 \\
10 \\
11 \\
12 \\
13 \\
14\end{array}$ & $\begin{array}{l}\mathbf{M} \\
\mathbf{M} \\
\mathbf{M} \\
\mathbf{M} \\
\mathbf{M} \\
\mathbf{M} \\
\mathbf{M} \\
\mathbf{M} \\
\mathrm{F} \\
\mathrm{F} \\
\mathbf{F} \\
\mathrm{F} \\
\mathbf{M} \\
\mathbf{M}\end{array}$ & $\begin{array}{l}20 \\
\\
18 \\
28 \\
28 \\
? \\
29 \\
19 \\
? \\
26 \\
27 \\
17 \\
24 \\
25 \\
18\end{array}$ & $\begin{array}{l}1 \\
1 \\
1 \\
2 \\
? \\
7 \\
1 \\
1 \\
1 \\
1 \\
1 \\
1 \\
1 \\
1\end{array}$ & $\begin{array}{l}43 \\
32 \\
40 \\
35 \\
40 \\
36 \\
40 \\
40 \\
44 \\
33 \\
36 \\
40 \\
40 \\
40\end{array}$ & $\begin{array}{l}\text { Fever and bullous eruption } 2 \text { dy before birth; } \\
\text { caesarean section } \\
\text { Acute 'viral infection' } 3 \text { wk before delivery } \\
\text { Herpes-like blisters on lips and tongue } 3 \text { wk before delivery } \\
\text { No complications } \\
\text { No data } \\
\text { No complications } \\
\text { No data } \\
\text { No complications } \\
\text { No complications } \\
\text { No complications } \\
\text { Gonorrhoeal infection during pregnancy } \\
\text { No complications } \\
\text { Shirodkar procedure, caesarean section } \\
\text { No complications }\end{array}$ & $\begin{array}{l}3100 \\
1950 \\
3800 \\
2680 \\
4600 \\
1600 \\
4060 \\
3700 \\
3600 \\
2325 \\
2440 \\
3200 \\
3290 \\
3360\end{array}$ \\
\hline
\end{tabular}

TABLE II

Clinical Features

\begin{tabular}{|c|c|c|c|c|c|}
\hline \multirow{2}{*}{$\begin{array}{l}\text { Type of } \\
\text { Disease }\end{array}$} & \multirow{2}{*}{$\begin{array}{l}\text { Case } \\
\text { No. }\end{array}$} & \multicolumn{2}{|c|}{ Age (dy) of } & \multirow{2}{*}{ Outcome } & \multirow{2}{*}{ Remarks } \\
\hline & & $\begin{array}{c}\text { Skin } \\
\text { Manifestation }\end{array}$ & $\begin{array}{l}\text { Neurological } \\
\text { Manifestation }\end{array}$ & & \\
\hline Disseminated & $\begin{array}{l}1 \\
2 \\
3 \\
4 \\
5 \\
6 \\
7 \\
7 \\
9\end{array}$ & $\begin{array}{r}9 \\
5 \\
12 \\
8 \\
16 \\
13 \\
- \\
-\end{array}$ & $\begin{array}{r}5 \\
8 \\
11 \\
8 \\
16 \\
16 \\
10 \\
13 \\
5\end{array}$ & $\begin{array}{l}\text { Died at } 10 \mathrm{dy} \\
\text { Died at } 11 \mathrm{dy} \\
\text { Died at } 28 \mathrm{dy} \\
\text { Died at } 53 \mathrm{dy} \\
\text { Now } 6 \text { yr old, severely damaged } \\
\text { At } 4 \text { mth normal, except for slight } \\
\text { hyperreflexia } \\
\text { Died at } 11 \mathrm{dy} \\
\text { Stomatitis at } 10 \text { dy, died at } 23 \mathrm{dy} \\
\text { At } 1 \text { yr: spastic hemiplegia }\end{array}$ & $\begin{array}{l}\text { Treated with IDU } \\
\text { Recurring skin eruptions } \\
\text { till } 5 \text { yr } \\
\text { Treated with IDU } \\
\text { Marked eosinophilia }\end{array}$ \\
\hline $\begin{array}{l}\text { Symptoms mainly } \\
\text { in the skin }\end{array}$ & $\begin{array}{l}10 \\
11 \\
12 \\
13\end{array}$ & $\begin{array}{r}0 \\
0 \\
8 \\
11\end{array}$ & $\bar{Z}$ & $\begin{array}{l}\text { At } 3 \mathrm{yr}: \text { left eye blind, otherwise normal } \\
\text { At } 1 \mathrm{yr}: \text { normal } \\
\text { At } 1 \mathrm{yr}: \text { normal } \\
\text { At } 6 \mathrm{mth} \text { : normal }\end{array}$ & $\begin{array}{l}\text { Eosinophilia }\left(5300 / \mathrm{mm}^{3}\right) \\
\text { Eosinophilia }\left(8000 / \mathrm{mm}^{3}\right)\end{array}$ \\
\hline $\begin{array}{l}\text { CNS symptoms } \\
\text { only }\end{array}$ & 14 & - & 14 & At $1 \mathrm{yr}$ : normal & $\begin{array}{l}\text { Intermittent tremors up } \\
\text { to } 1 \mathrm{mth}\end{array}$ \\
\hline
\end{tabular}


Eleven (?12) of the mothers were primiparae. 3 of them had symptoms suggesting a viral (?herpetic) infection shortly before delivery (Cases 1,2 , and 3 Table I). In 1 of these a serological diagnosis of HSV type 2 infection was made post partum (Case 3). 2 of the children were delivered by caesarean section; in both cases the membranes had ruptured more than 24 hours before the operation. 4 of the children weighed less than $2500 \mathrm{~g}$ at birth, and only 1 of these was 'small-for-dates' (Case 6).

Clinically, 9 of our cases (Cases 1-9) had a disseminated form of the disease. In this group the first sign of illness in 5 cases was a vesicular eruption on the skin and in 1 case a vesicular stomatitis. In 1 case neurological symptoms preceded the skin eruption, and in 2 no skin symptoms were observed. The age at the appearance of the first symptoms varied from 4 to 16 days. All the children in this group had severe neurological symptoms later during their illness. 6 of these 9 children died. One (Case 5) was left with severe brain damage: he also had repeated skin eruptions up to the age of 5 years. Another child (Case 9) has a spastic hemiplegia, and only 1 child (Case 6) seems to have survived without severe sequelae.

At necropsy the findings were those usually described in cases of newborn herpetic infection, i.e. necrotizing encephalitis and visceral involvement of varying degree.

Of the 4 children who had mainly skin symptoms, 2 already had a vesicular eruption at birth (Cases 10 and 11). In Case 10 the vesicles covered the whole body except the palms of the hands and soles of the feet: later new vesicles appeared mostly on the left side of the body, the eruption subsiding at the age of 3 months. A retinitis juxtapapillaris was observed at the age of 2 months and this eye became blind. In other respects, this child at 3 years is quite healthy.

The other child (Case 11) had vesicles on both arms at birth. The eruption subsided in one month. No other signs of illness were observed and later development was normal. This was the only case in which virus could not be isolated from vesicles in spite of several attempts, though the virus was isolated from the throat.

Both these children with skin symptoms at birth showed an unusually high peripheral eosinophilic count, $8000 / \mathrm{mm}^{3}$ and $5300 / \mathrm{mm}^{3}$. Both had normal amounts of $\operatorname{IgM}$ in their sera.

One of the children (Case 14) had CNS symptoms only. He was admitted to hospital because of fever and tremor. The CSF contained $40 \mathrm{WBC} /$

TABLE III

Virological Data

\begin{tabular}{|c|c|c|c|c|c|c|c|}
\hline \multirow{3}{*}{ Case No. } & \multirow{3}{*}{$\begin{array}{c}\text { Clinical } \\
\text { Isolation }\end{array}$} & \multirow{3}{*}{$\mathrm{FA}^{\star}$} & \multirow{3}{*}{$\begin{array}{l}\text { Necropsy } \\
\text { Isolation }\end{array}$} & \multirow{3}{*}{$\begin{array}{c}\text { Serum } \\
\text { Samplet }\end{array}$} & \multicolumn{3}{|c|}{ Antibody Titres } \\
\hline & & & & & CF & IFAT ${ }^{\star}$ & IFAT* \\
\hline & & & & & & Type 1 & Type 2 \\
\hline 1 & $\begin{array}{l}\text { Throat } \\
\text { Vesicle }\end{array}$ & - & $\begin{array}{l}\text { Brain } \\
\text { Heart } \\
\text { Lung }\end{array}$ & I & $<4$ & 20 & 10 \\
\hline 2 & - & - & Brain $\ddagger$ & - & - & - & - \\
\hline 3 & Vesicle $\ddagger$ & Negative & Brain $\ddagger$ & $\begin{array}{l}\text { I } \\
\text { II }\end{array}$ & $\begin{array}{l}32 \\
16\end{array}$ & $\begin{array}{l}40 \\
40\end{array}$ & $\begin{array}{l}40 \\
40 \\
\end{array}$ \\
\hline 4 & $\begin{array}{l}\text { Vesicle } \\
\text { Throat }\end{array}$ & $\begin{array}{l}\text { Vesicle } \\
\text { Throat }\end{array}$ & $\begin{array}{l}\text { Brain } \ddagger \\
\text { Heart }\end{array}$ & I & $\begin{array}{r}<8 \\
8\end{array}$ & $\begin{array}{l}20 \\
10\end{array}$ & $\begin{array}{r}10 \\
320 \\
\end{array}$ \\
\hline 5 & Vesicle & - & - & $\begin{array}{l}\text { I } \\
\text { II }\end{array}$ & 二 & $\begin{array}{l}40 \\
80\end{array}$ & $\begin{array}{r}10 \\
160 \\
\end{array}$ \\
\hline 6 & Vesicle & Vesicle & - & I & $\begin{array}{r}<8 \\
8\end{array}$ & $\begin{array}{l}20 \\
40\end{array}$ & $\begin{array}{r}<10 \\
40 \\
\end{array}$ \\
\hline 7 & - & 一 & Lung & - & - & - & - \\
\hline 8 & Vesicle & 一 & - & $\begin{array}{l}\text { I } \\
\text { II }\end{array}$ & $=$ & $\begin{array}{r}<10 \\
10\end{array}$ & $\begin{array}{r}<10 \\
20 \\
\end{array}$ \\
\hline 9 & Vesicleł & Vesicle & 一 & II & $\begin{array}{l}16 \\
32\end{array}$ & $\begin{array}{l}40 \\
40\end{array}$ & $\begin{array}{l}20 \\
20\end{array}$ \\
\hline 10 & $\begin{array}{l}\text { Vesicle } \\
\text { Throat }\end{array}$ & 一 & - & $\begin{array}{l}\text { I } \\
\text { II }\end{array}$ & $\begin{array}{l}32 \\
16\end{array}$ & $\begin{array}{l}40 \\
20\end{array}$ & $\begin{array}{l}20 \\
10\end{array}$ \\
\hline 11 & Throat & Throat & 一 & II & $\begin{array}{r}16 \\
8\end{array}$ & $\begin{array}{l}20 \\
20\end{array}$ & $\begin{array}{r}<10 \\
10\end{array}$ \\
\hline 12 & $\begin{array}{l}\text { CSF } \\
\text { Vesicle }\end{array}$ & Vesicle & - & $\begin{array}{l}\text { I } \\
\text { II }\end{array}$ & $\begin{array}{l}32 \\
32\end{array}$ & $\begin{array}{l}40 \\
40\end{array}$ & $\begin{array}{l}40 \\
40\end{array}$ \\
\hline 13 & CSF & 一 & 一 & II & $\begin{array}{l}32 \\
16\end{array}$ & $\begin{array}{l}20 \\
10\end{array}$ & $\begin{array}{l}20 \\
20\end{array}$ \\
\hline 14 & $\begin{array}{l}\text { CSF } \\
\text { Throat }\end{array}$ & 一 & 一 & I & $\begin{array}{r}128 \\
32\end{array}$ & $\begin{array}{l}80 \\
20\end{array}$ & $\frac{1}{10}$ \\
\hline
\end{tabular}




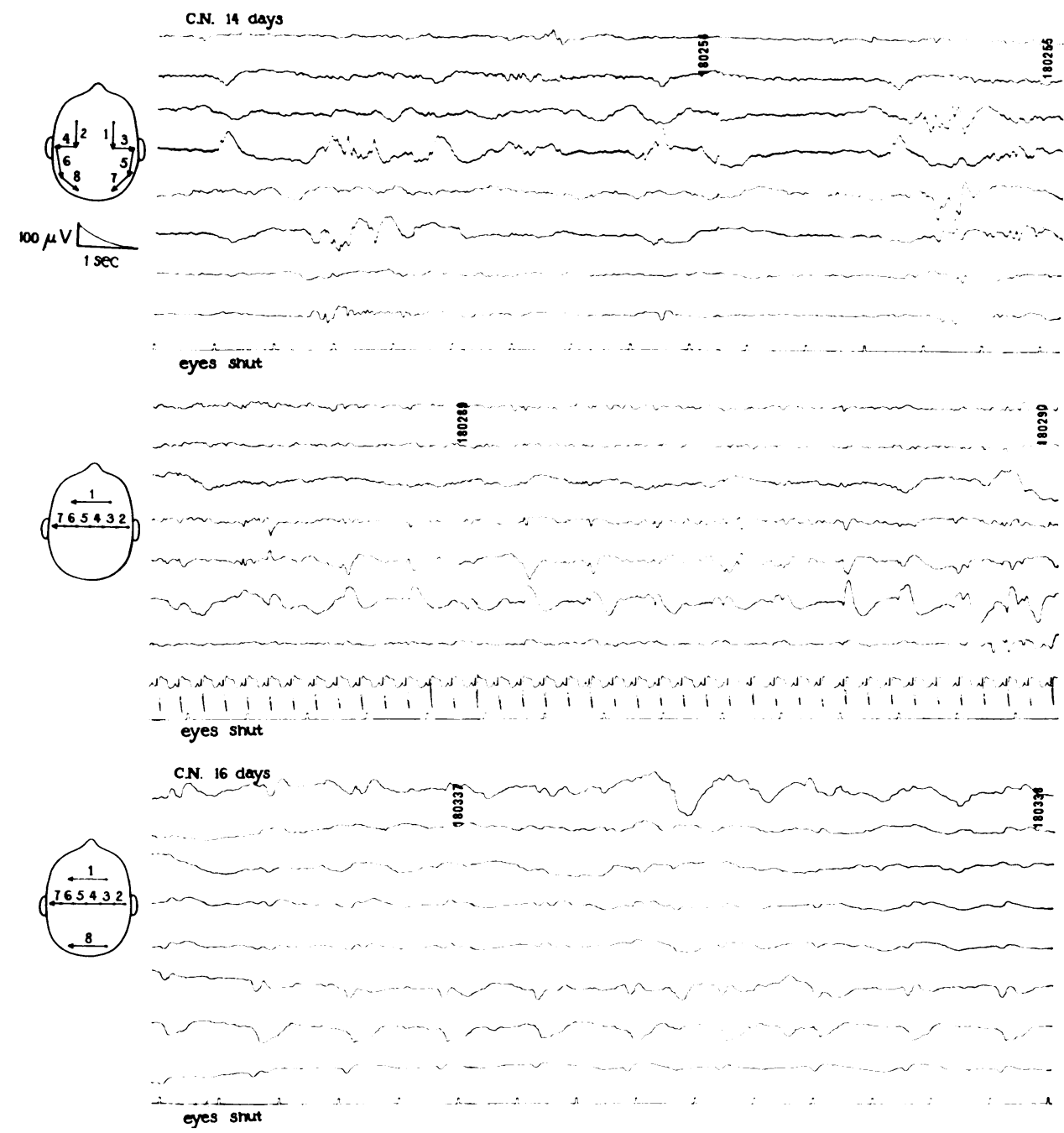

FIG. 1.-Case 6: EEG at 14 and 16 days of age. At 14 days, sharp waves are seen in both temporal regions. At 16 days, sharp waves in the region of the left sylvian fissure are seen recurring at a rate of 1 to 1.5 sec and triangular shaped waves occur in the left sylvian region with an interval of about $1.5 \mathrm{sec}$.

$\mathrm{mm}^{3}$ and the protein content rose to $180 \mathrm{mg} / 100$ $\mathrm{ml}$. The EEG showed periodic complexes of sharp waves. Intermittent tremor continued for one month, but then subsided and no later sequelae have been observed.

Virological findings. The sources of virus isolations are shown in Table III. Isolation from a vesicle was attempted in 9 cases and was successful in 8 . In 3 cases the virus was isolated from CSF, in 1 case from the throat, and in 2 cases from necropsy specimens from the brain and lung. As the method for typing the virus has been available only since 1969, only 6 isolates have been typed; all were of type 2 (Cases 2, 3, 4, 6, 9, and 11).

In 5 cases herpes virus antigen could be demonstrated by FA-technique from vesicles or throats. In 1 case $\mathrm{FA}$ was negative in spite of positive virus isolation (Case 3).

Using the CF test no antibody responses could be detected in the 10 patients studied. With the IFAT technique, 4 out of the 12 studied showed a fourfold or more rise in type 2 antibodies. All 4 had a disseminated form of the disease. In the others the level of herpes antibodies was mostly constant (Table III) 
Electroencephalography. In 6 patients (Cases 3, 4, 6, 9, 10, and 14) the EEG was recorded several times during the first weeks or months. 5 had neurological symptoms and showed marked EEG abnormalities. 4 showed an attenuation of the activity, either generalized or predominant over one hemisphere. In 2 patients, who later died, the attenuation was severe and some days before death little or no activity was seen.

All 5 showed bursts of sharp waves on alternating sides in the temporal, central, or occipital regions.

Periodic complexes were also seen in all 5 (Fig. 1 and 2). These usually consisted of triangular or sharp waves, and were often restricted to one region. These waves were observed when the patients were awake and when they were drowsy, possibly also in light sleep. They were seldom continuous, but were usually seen during periods varying from 5-25 seconds. The interval between the complexes was 1.5-3 seconds. These complexes were seen during the early weeks of the disease, but in one case up to the age of 5 months.

The one patient without neurological symptoms (Case 10) had a normal EEG.
In 1 patient (Case 5) the EEG was recorded only at the age of 4 years. He was severely disabled, was not able to move, but could swallow, and also had some contact with his nurse. The EEG was flat, and no electrical activity could be seen.

\section{Case Reports}

Two children were treated with systemic IDU, and these cases are described in more detail.

Case 4. A boy, the second child of a mother aged 28 , whose pregnancy was uneventful, but where the delivery was premature at 35 weeks (birthweight $2680 \mathrm{~g}$ ), appeared entirely normal until the age of 8 days, when he appeared jaundiced and ill and developed a few vesicles on the trunk. At 10 days he was admitted to hospital, where meningoencephalititis was diagnosed. The CSF contained: leucocytes $330 / \mathrm{mm}^{3}$, glucose $31 \mathrm{mg} / 100 \mathrm{ml}$, and protein $97 \mathrm{mg} / 100 \mathrm{ml}$. The serum bilirubin value was $9.6 \mathrm{mg} / 100 \mathrm{ml}$. Three vesicles were seen, two close to the umbilicus, one between the scapulae. Herpes virus antigen could be shown in these by the immunofluorescent technique. EEG at 13 days was abnormal, but difficult to interpret. The general condition worsened and at 17 days symmetrical convul-
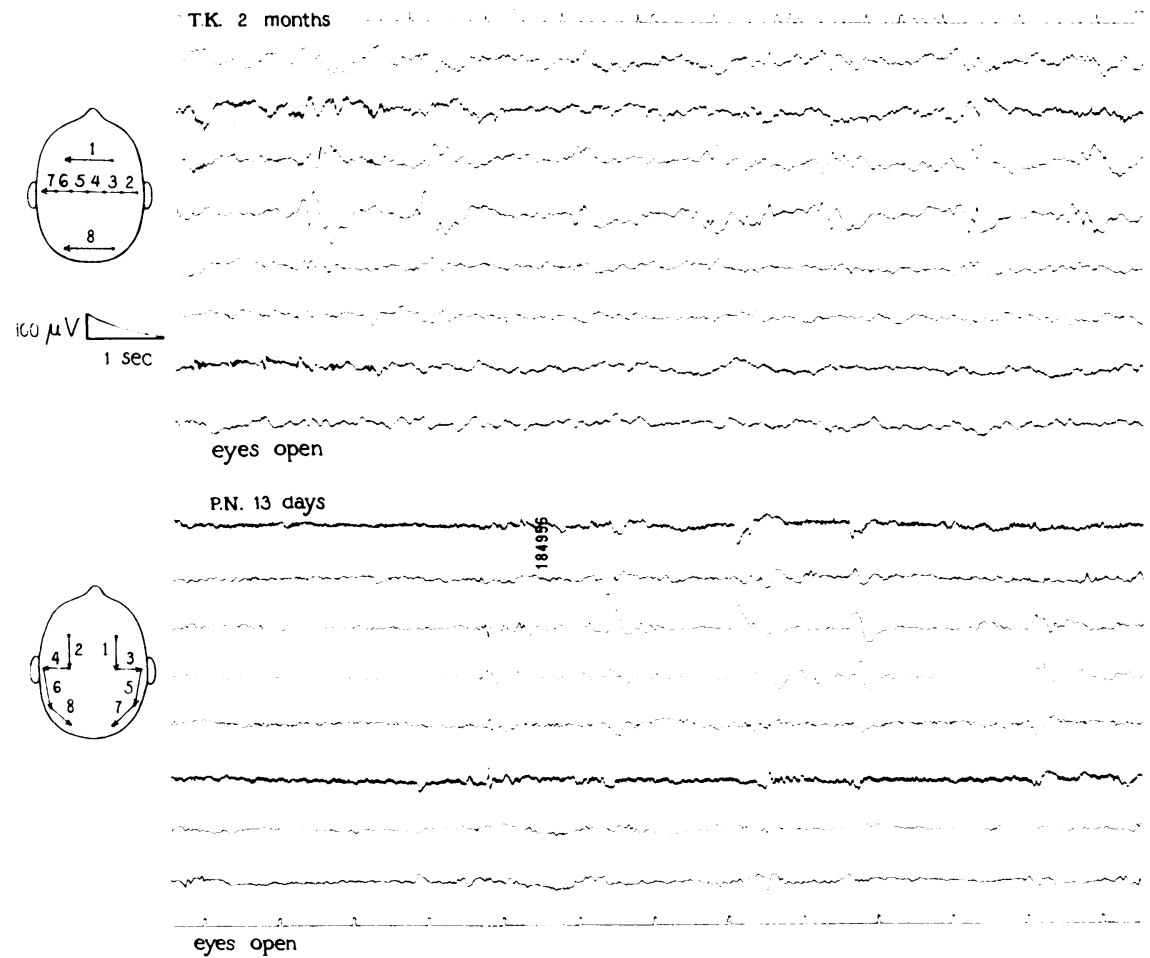

FIG. 2.-EEGs. Upper tracing, Case 9, aged 2 months: periodic triangular waves are seen over both hemispheres with an interval between waves of about $1.5 \mathrm{sec}$. Lower tracing, Case 4, aged 13 days: similar waves occur predominantly in the central region. 
sions of a few seconds' duration were observed; at that time the EEG showed periodic complexes. At 22 days IDU treatment was started. The dose was $55 \mathrm{mg} / \mathrm{kg}$ per day for 5 days. The general condition deteriorated however, and two weeks later practically no electrical activity could be seen in the EEG. He died at the age of 53 days.

At necropsy extensive subdural haematomas could be seen. Liver, spleen, adrenals, and thymus were normal. Virus was isolated from necropsy specimens of brain and heart.

Case 6. A male was born to a 29-year-old woman who previously had 4 deliveries and 2 abortions. The delivery was normal after 36 weeks' gestation, but the infant weighed only $1600 \mathrm{~g}$. The Apgar score was 7 at 1 minute and 8 at 10 minutes. Because of prematurity he was transferred to the Children's Hospital. IgM concentration was less than $8 \mathrm{mg} / 100 \mathrm{ml}$. At age 12 hours an exchange transfusion was done because of a rise in the serum bilirubin to $6 \mathrm{mg} / 100 \mathrm{ml}$. Before the transfusion some petechiae were observed on his chest. The thrombocyte count was $104,000 / \mathrm{mm}^{3}$. As bacterial infection was suspected, treatment with gentamycin was started. Some fresh petechiae appeared on the following day but the general condition remained satisfactory.

At 14 days herpes-like blisters were observed on the lip and a day later in the mouth also. The first EEG taken at that time was abnormal, but of poor technical quality. In a recording two days later the activity was periodically attenuated, alternating with periods of compexes of sharp theta waves. By that time herpes antigen had been demonstrated in the blisters by immunofluorescent staining. Virus isolation was also successful, and was found to be herpes virus type 2 .

At 16 days he was febrile; CSF, WBC $32 / \mathrm{mm}^{3}$, glucose $41 \mathrm{mg} / 100 \mathrm{ml}$, and protein $95 \mathrm{mg} / 100 \mathrm{ml}$. On that day IDU treatment was begun, by intravenous drip, $60 \mathrm{mg} / \mathrm{kg}$ per day for 7 days.

At first his general condition deteriorated quickly, and he became grey, and opisthotonic. On the fourth day of treatment the EEG was grossly abnormal: activity was severely attenuated especially on the right side, and almost no activity was seen in the occipital regions; periodic bursts of sharp waves were seen predominantly on the left side.

During this phase of the disease, head circumference decreased $1.5 \mathrm{~cm}$ and the skull bones became overlapping, though he was not clinically dehydrated. After 4 days a surprising inprovement set in, and by the age of 26 days the child had begun to thrive, the neurological signs had almost disappeared, and the EEG was nearly normal. This improvement continued and the child returned home at the age of 8 weeks.

During IDU treatment the white blood cell count of the peripheral blood varied between 9500 and 15,900/ $\mathrm{mm}^{3}$. The thrombocytes diminished from $248,000 /$ $\mathrm{mm}^{3}$ at the beginning to 16,600 on the day treatment was stopped; 2 days later they rose to $274,000 / \mathrm{mm}^{3}$. $\mathrm{Hb}$ dropped from 13.9 to $9 \cdot 2 \mathrm{~g}$ and was corrected with a transfusion.
At the age of 4 months the child appeared to be $\frac{\bar{C}}{\bar{C}}$ normal apart from slight hyperreflexia and the EEG was also normal.

\section{Discussion}

The finding that both genital and newborn $\overrightarrow{0}$ herpes infections are caused by HSV type 2 is $\overrightarrow{\vec{\omega}}$ strongly in favour of a maternal herpetic infection $\mathrm{O}$ as the source of the neonatal disease. We were able to ascertain the type of the causative agent in $6 ?$

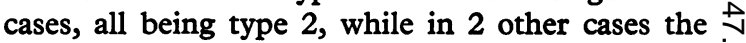
serological response was of type 2. Nahmias et al. ज (1967) have shown that herpes virus can be isolated $\overrightarrow{.}$ from the cervix more often during late pregnancy $\forall$ than in the earlier phases. In a preliminary survey $\frac{0}{x}$ for herpes virus antigen in cervical smears we studied 100 mothers randomly chosen at delivery. Immunofluorescent staining with rabbit antiherpes antisera gave a positive result in 10 cases. In a control examination a few weeks later only one of the mothers had herpes antigen.

The clinical pattern in newborn herpes infection N has been divided into different types by Nahmias et al. (1970), but the fact that such a division is somewhat arbitrary is exemplified by Case 10 who had only skin symptoms in the newborn period, but later became blind in the left eye due to retinitis. In 2 further cases (12 and 13) no neurological symptoms were observed, but virus was isolated from the CSF.

The results of treatment of disseminated newborn HSV infection with IDU are hard to evaluate. The poor outcome in most instances might be due to treatment beginning too late (Partridge and Millis, 1968; Golden et al., 1969; Tuffli and Nahmias, 1969; Charnock and Cramblett, 1970). An early diagnosis must be of paramount importance. We have tried to achieve this using the FA technique to identify herpes antigen, and the EEG to diagnose an incipient herpetic encephalitis.

Periodic complexes in the EEG in HSV encephalitis have been described by several authors in adult cases. Some authors find them to be of great diagnostic help, but others stress their unspecificity (Ekelund and Hagbarth, 1964; Upton and Gumpert, 1970; Scott and Prior, 1970). Many of the disorders in which repetitive complexes are also seen, such as subacute sclerosing panencephalitis and some tumours, are unlikely to occur in neonates. On the other hand, anoxia and encephalitis of other than herpes aetiology, might give rise to similar changes in the EEG. In our experience, however, periodic complexes have been a prominent finding only in HSV encephalitis. We suggest that treatment with IDU is justified if the clinical picture is compatible with HSV infection, herpes antigen can be 
demonstrated by the FA technique, and the EEG shows typical periodic complexes.

Two of our cases were treated with IDU. In the first the drug was probably only given when irreversible brain damage had already occurred. In the other case the treatment was begun on the third day after the appearance of symptoms, with subsequent full recovery.

Of our 9 cases with disseminated disease, 6 died, 1 is severely damaged, 1 is hemiplegic, and the only one who seems to have recovered is the child who received IDU treatment early. Further trials with IDU beginning as early as possible in the disease are required.

We thank Miss Raija Lahdensivu and Mrs. Pirkko Leino for technical help. This work was supported by the Medical Research Council of Finland and the Foundation for Paediatric Research.

\section{REFERENCES}

Bellanti, J. A., Catalano, L. W., Jr., and Chambers, R. W. (1971). Herpes simplex encephalitis: virologic and serologic study of a patient treated with an interferon inducer. Fournal of Pediatrics, 78, 136.

Charnock, E. L., and Cramblett, H. G. (1970). 5-iodo-2-deoxyuridine in neonatal Herpesvirus hominis encephalitis. Fournal of Pediatrics, 76, 459.

Ekelund, H., and Hagbarth, K. E. (1964). Herpes simplex encephalitis with major EEG changes in children (Swedish). Svensk Läkartidningen, 61, 2383.

Golden, B., Bell, W. E., and McKee, A. P. (1969). Disseminated herpes simplex with encephalitis in a neonate: treatment with idoxuridine. Fournal of the American Medical Association, $209,1219$.

Leinikki, P. (1971). Immunofluorescent assay of herpes virus type 1 and type 2 antibodies in rabbit and human sera. Archiv für gesamte Virusforschung. (In press.)
Nahmias, A. J., Alford, C. A., and Korones, S. B. (1970). Infection of the newborn with Herpesvirus hominis. Advances in Pediatrics, 17, 185.

Nahmias, A. J., Chiang, W. T., Del Buono, I., and Duffey, A. (1969a). Typing of Herpesvirus hominis strains by a direct immunofluorescent technique. Proceedings of the Society for Experimental Biology and Medicine, 132, 386.

Nahmias, A. J., and Dowdle, W. R. (1968). Antigenic and biologic differences in Herpesvirus hominis. Progress in Medical Virology, 10, 110.

Nahmias, A. J., Dowdle, W. R., Josey, W. E., Naib, Z. M., Painter, L. M., and Luce, C. (1969b). Newborn infection with Herpesvirus hominis types 1 and 2. Fournal of Pediatrics, 75, 1194.

Nahmias, A. J., Naib, Z. M., Josey, W. E., and Clepper, A. C. (1967). Genital herpes simplex infection: virologic and cytologic studies. Obstetrics and Gynecology, 29, 395.

Partridge, J. W., and Millis, R. R. (1968). Systemic herpes simplex infection in a newborn treated with intravenous idoxuridine. Archives of Disease in Childhood, 43, 377.

Plummer, G., Waner, J. L., Phuangsab, A., and Goodheart, C. R. (1970). Type 1 and type 2 herpes simplex viruses: serological and biological differences. Fournal of Virology, 5, 51.

Salo, O., Virkola, P., Palosuo, T., and Lassus, A. (1969). Die Diagnose der durch das Herpes Simplex-Virus verursachten Hautverănderungen mit Hilfe der Fluorescenz-AntikörperMethode. Hautarzt, 20, 112.

Schneweis, K. E. (1962). Serologische Untersuchungen zur Typendifferenzierung des Herpesvirus hominis. Zeitschrift für Immunitätsforschung, 124, 24.

Schneweis, K. E. (1967). Die Typen 1 und 2 des Herpes-simplexVirus bei verschiedenen Krankheitsbildern. Deutsche Medizinische Wochenschrift, 92, 2313.

Scott, D. F., and Prior, P. F. (1970). The EEG in herpes-simplex encephalitis. Lancet, 2, 525.

Tuffli, G. A., and Nahmias, A. J. (1969). Neonatal herpetic infection: report of 2 premature infants treated with systemic use of idoxuridine. American Fournal of Diseases of Children, $118,909$.

Upton, A., and Gumpert, J. (1970). Electroencephalography in diagnosis of herpes-simplex encephalitis. Lancet, 1, 650.

Correspondence to Dr. P. Leinikki, Department of Virology, University of Helsinki, Haartmanink 3, 00290 Helsinki 29, Finland. 